\title{
Camp land: Settler ecotourism and Kazakh removal in contemporary Xinjiang*
}

Guldana Salimjan

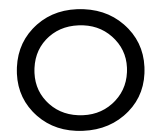
$\mathrm{n}$ a summer day in 2015, at Tianshan's Bogda Lake with a friend who had come to visit Xinjiang, I felt out of place in my homeland. At the bus terminal by the lake, which Chinese tourists refer to as Tian Chi (天池) or 'the basin of heaven', the tour guide drew on romanticised cultural stereotypes to introduce my people to the tourists. 'The Kazakhs', she said, 'are nomads who move the most in the world' (世界上搬家最多的民族). Ironically, in the past decade, Kazakhs, along with many other mobile pastoral groups in China-Tibetans, Mongols, Kyrgyz, Tuvans, and Evenks-have been pressured by the Chinese Government to give up their pastoral life via policies that call for 'returning the pastures to the grassland' (退牧还草). When we got off the bus, I was greeted by a sign that read, 'Kazakh Ethnic Culture Garden', behind which stood dozens of yurts tightly packed against one another. At the entrance to this 'garden', there was a cross-section of a yurt beside an eagle and several replicas of balbal statues-ancient anthropomorphic stone stelae that can be found on the Eurasian steppe. Kazakh and Uyghur dancing costumes hung on the yurt wall for tourists to be photographed wearing. As I was taking in this Disneyfied display of Kazakh nomadic culture, a group of Kazakh locals approached the tourists getting off the bus and asked them whether they would like to stay for a night in their yurts. I immediately realised that this was their job-to conduct tourism.

That day, I was the only Kazakh among the Han and foreign tourists who visited Bogda Lake. The tourists were led to see we Kazakhs as simple people clinging to a primitive culture. I saw Kazakh boys the age of my

\footnotetext{
* This article was originally published in Lausan on I September 2021. The author wishes to thank Sam H. Bass, Darren Byler, Stevan Harrell, as well as the editors at Lausan for valuable feedback. Additionally, the author thanks activist Erkin Azat and the Xinjiang Victims Database for their important documentation work on the Xinjiang crisis.
} 
younger cousins renting out their horses for Han tourists to ride, and Kazakh women and men cooking food to serve the tourists, charging them RMB50-100 for food and lodging. They were engaging in a 'Herder Family Happiness' (牧家乐) business model that followed the 'Peasant Family Happiness' (农家乐) model of rural tourism in other Chinese provinces. The lake was unrecognisable from the times I had visited the mountains we call Tengri Tau as a child. On the grassland that herders had once used as their mountain pastures, Chinese-language songs blared from loudspeakers disguised as tree trunks in the woods, and the sound of a bell from a newly built Taoist temple echoed in the mountains. The name 'Flying Dragon Pond' (飞龙潭) was calligraphically carved into the cliff next to the lake, and pavilion-shaped tourist boats explored its waters. Tourist signage designated Bogda Lake as the foot-bathing tub of the mythical Taoist goddess Xiwangmu (西王母的洗脚盆), rendering the landscape of the Central Asian steppe indistinguishable from tourist sites in eastern Chinese provinces.

In 2005, the regional government began to relocate herders, farmers, and miners out of the Bogda Lake area; in the process, more than 1,322 households became 'ecological migrants' (生态移民). In 2012, for the Tianshan region to meet the requirements of its application for designation as a UNESCO World Heritage site, the regional government implemented a grazing ban on 100 square kilometres of pasture around the lake and demolished the shops and buildings there (SCIO 2012; Chinanews.com 2012). Since a state-owned tourism company named Western Regions (西域旅游) took over management of the area, even the locals who used to live there must pay RMB215 to access the lake. Similarly, in 2013, in an effort to develop its tourist industry, the government of the Bortala Mongol Autonomous Prefecture banned grazing on the 110 square kilometres surrounding Sayram Lake, displacing 600 households of herders and 120,000 head of livestock (Bortala People's Government 2017). By 2017, the off-limits area had increased to 127 square kilometres (see also Salimjan 2021b). Most of the tourist sites in northern Xinjiang were inhabited by Kazakh, Mongol, Kyrgyz, and Tuvan herders, on mountainous prairies with rich water resources, such as Sayram Lake, Bogda Lake, Kanas (Qanas) Lake in Altay, and the Narat and Qarajon (Ch: Kalajun, 喀拉峻) prairies in the Ili River Valley. After China's successful application for World Heritage status in 2013 for the Tianshan region-which includes Qarajon-Qurdnin, Bogda Lake, Bayanbulak Lake, and Tömür Choqqisi (Tomur Peak) in Aksu-tourism boomed. 
At the Kazakh Ethnic Culture Garden at Bogda Lake, an old couple who had been relocated from their land told me how their lives had been disrupted by their 'ecological migration' and the boom in the private tourism sector:

We have been doing tourism for quite a while. Back then we had a better location, quite close to the lake. It was quiet and beautiful; we had a lot of guests. They would stay for a night and hike into the mountains the next day. We had a lot of traveller friends. We had livestock and we had a tourism business. Then ... we had to move here. The pastures at the top of the mountain were fenced up, and we had to sell our livestock ... many people had to sell livestock. Some people left, some stayed and kept doing tourism. But there are not as many guests as before, and they seldom stay either. We can only rely on tourism now. We used to make about RMB2,000 a day when the business was good, and then most Kazakhs in Sangong County were displaced. Only 100 families were allowed to stay since they had worked in tourism before.

The artificial, manufactured tourist landscape at Bogda Lake, which reduces Kazakhs who have lived on their land for generations to a mere commodity, is only the tip of the iceberg in the systemic dispossession of Turkic peoples and other minorities in Xinjiang. Over the past few years, global attention has focused on the gross violations of human rights such as arbitrary detentions and technological surveillance in Xinjiang. However, there remains a lack of understanding about the relationship between disappearing lifeways and developmental projects that had encroached on native land before the Muslim crackdown even started, let alone attention to the plight of Kazakh pastoralists in northern Xinjiang. In this essay, I delineate a brief history of Kazakh dispossession after China entered its 'ecologically conscious' developmental stage. During this time, not only have Kazakh pastoralists been violently displaced for the sake of the 'ecological restoration' of their grasslands, but also their land and livelihoods have become exploitable resources for the development of ecotourism. The state's crackdown on Muslims, which accelerated from 2017, has facilitated the imprisonment of Kazakh land petitioners as well as the confiscation of their land; Kazakhs have been coerced with the threat of detention to give up their traditional lands and lifeways. 


\section{Ecotourism as greenwashing and settler place-making in Xinjiang}

The CCP's commitment to achieving an 'ecological civilisation' (生态文 明), which was written into China's constitution in 2012 as a response to nationwide environmental problems, undergirds the scientific discourse of 'ecological conservation' (生态保护) as a solution for grassland degradation. In pastoral regions, top-down directives have stimulated state-led conservation work that excludes indigenous populations from being stakeholders in grassland resource management. Most pastoralists in China are state-designated 'minority nationalities' (少数民族) who make up only 1.3 per cent of the national population but who inhabit the vast grasslands that make up 40.9 per cent of the country's territory (Pan 2015). As China entered its more 'ecologically conscious' stage of development, state scientists disproportionately ascribed grassland degradation to 'irresponsible' herders overgrazing their animals, rather than the environmentally destructive operations of state-owned agricultural and extractive industries. After all, 70 per cent of China's domestic coal is exported from its settler colonies in the periphery, such as Inner Mongolia and Xinjiang, to eastern China to fuel its resource demands (Cornot-Gandolphe 2014).

The plight of Kazakh and other nomadic pastoralist communities resonates with the past and present plight of indigenous communities around the world, in that state-led enclosures of Kazakh grassland find their echoes in the colonial land grabs that have taken place globally. For instance, in Norway, the development of wind farms on reindeer-herding lands as part of the government's climate change-mitigation strategy has endangered the life systems and ecological practices of Sami reindeer herders (Fjellheim and Carl 2020; Normann 2021). It has been documented how the United Nations' REDD+ initiative aimed at reducing emissions from deforestation and forest degradation undermines local farmers in countries as diverse as Mozambique, Nigeria, Democratic Republic of Congo, Madagascar, Brazil, Indonesia, Peru, Uganda, and Kenya (WRM and GRAIN 2015). In the United States, the establishment of national parks occurred in the context of the dispossession and genocide of indigenous peoples (Treuer 2021). Before the founding of Yosemite National Park, members of a California state militia razed the villages of, and murdered, the Miwok who had been obstructing the frenzy of extraction brought 
about by the goldrush. Yellowstone National Park was established in 1872 while the Plains Wars raged around its borders, and the Yellowstone Act of 1872 criminalised Shoshone and Bannock peoples' access to the park, barring them from hunting and foraging within its boundaries. In Panama, the Amistad International Biosphere Reserve was established in the aftermath of the US invasion in 1989, after which Naso, Ngobe, and other forest-dwelling communities were removed from the reserve (Landesman 2018). The Panamanian Government granted Texaco drilling rights over 405,000 hectares within the biosphere in 1990. The World Bank's Global Environmental Facility-in tandem with the World Wildlife Fund, Conservation International, and the Nature Conservancy-subsequently took charge of the biosphere's land management program and funded unsuccessful 'alternative livelihood' microprojects and ecotourism initiatives to compensate the impacted forest-dwellers.

In China, state directives sought to extinguish indigenous ways of being on and relating to the land. The ecological civilisation's mandate of scientific conservation and pollution reduction considers mobile pastoralism a backward enterprise that should be abandoned. In this context, herders must adapt to Chinese settler-society norms and settle down, so they can enjoy a 'modern, civilised life' that provides 'stable wages that enable investment in small businesses' (SCIO 2015; Sun 2019). Official media often frame sedentarisation as an improvement of herders' quality of life because they no longer have to seasonally migrate to avoid harsh weather. Moreover, the state has claimed that sedentarisation brings better education, medical care, and employment opportunities. Not only does this paternalistic narrative exaggerate the difficulties of mobile pastoralism, and neglect mobility as an integral part of Kazakh pastoral identity, it also construes pastoralism as incompatible with state modernity and sees sedentarisation as a way to modernise Kazakhs to make them feel grateful towards the Party-State-when, in fact, the Kazakh community in Xinjiang has long cultivated urban and rural social networks to navigate urban life and access urban resources. However, it seems that policies on grazing bans and sedentarisation, which started to be implemented in 2002, have encountered numerous obstacles and therefore have been less successful than expected, at least judging from the central government's insistence that propaganda work is important (see, for instance, National 
Forestry and Grassland Administration 2020). It is in this context that the central government set the goal in 2011 of permanently banning grazing on 100,000 square kilometres of land in Xinjiang (Guan and Zhao 2011). In 2015, the Xinjiang Uyghur Autonomous Region (XUAR) Party Committee issued strict environmental assessments and regulatory measures, instituting grazing bans to force the relocation of herders so their grasslands could be rehabilitated (Wang 2017).

Kazakhs' relationship to their land and their mode of land stewardship, mobile pastoralism, have been invalidated according to the paternalistic, legalistic formulations of settler-state sovereignty (Akins and Bauer jr 2021; Moreton-Robinson 2021). Genealogical narratives entangled with land histories are important aspects of Kazakh self-identification. Kazakhs invoke the names of their homeland in turns of phrase such as ata-babamizding jeri ('land of our ancestors'), atameken ('homeland of our forefathers'), and kindik qanim tamgan jer ('land where my umbilical blood was shed'). The names of khans, khojas ('Islamic missionaries'), and batirs ('heroes') who fought for the people are an integral part of local histories and are sometimes kept as placenames. However, these historical markers are often dismissed by the state as folkloric and were even forbidden during high-socialist periods like the Cultural Revolution because they were 'feudalistic' (Salimjan 2021a). To 'restore' nature to its 'original' 'pristine' state (素面朝天, 还其自然), Xinjiang's native community and economy are sidelined and rendered disposable. When a mass internment system was introduced in 2016, the rhythms of removal and theft sped up, proliferating across Kazakh lands.

Coercive ecological conservation came hand in hand with the development of rural tourism and other forms of ecotourism to generate new sources of revenue off land that is undergoing 'ecological rehabilitation'. In Xinjiang, conservation policies to 'return' the land to 'nature' take their cues from the model of de-industrialisation and ecotourism (生态旅游) first pioneered in Anji County, Zhejiang Province, the ethos of which is encapsulated by the slogan 'clear waters and green mountains are mountains of gold and silver' (绿水青山就是金山银山). This slogan is a quote from Xi Jinping when he visited Anji County in 2005, when he was Zhejiang's Party Committee Secretary, and was codified into an aphorism and even written into the Chinese Constitution in 2017 as one of the tenets of the ecological civilisation. It has since featured prominently in the government's calls for the Anji County model to be adopted nationwide. China's Twelfth Five-Year Plan designated Xinjiang as an 
up-and-coming major tourist destination, with southern Xinjiang to be developed into a showcase for the ancient Silk Road and its folk cultures (XUAR Government 2009; CNTA 2015). As the crackdown on Turkic Muslims has accelerated since 2017, local governments have revamped more and more Uyghur villages in the south into tourist sites in the name of poverty alleviation (see Song 2020; Zero Distance Moyu 2019; YouTube 2021b). Meanwhile, in the north, places from which Kazakh and other pastoralist communities were displaced are branded as locations where tourists can appreciate 'nature', recalling the way in which American national parks were construed as 'virgin' wilderness where settlers could worship the sublime. Many pastoralists-dispossessed by Han settlers or by state authorities enforcing 'ecological conservation'-have had to commodify their culture, just like the Uyghurs in the south, and cater to the tourist gaze to make a living. The violence that undergirds these similar but distinct developments in the north and south is masked with innocuous soundbites from Chinese tourism sites that advise tourists to 'see nature in northern Xinjiang and culture in southern Xinjiang' (北疆 看景观, 南疆看人文) (Sohu.com 2020).

Since 2017, counterterrorism campaigns and surveillance technology have engulfed Xinjiang entirely, consolidating what Darren Byler (2022) calls 'terror capitalism', in which cheap, unfree labour is marshalled to secure profits for the region's industrial complexes. Environmental conservation and tourism constitute another site where indigenous land and bodies are capitalised. ${ }^{1}$ Tourism in settler societies like the Panamanian Caribbean and Hawai 'i often caters to privileged, affluent settlers and foreigners, and is predicated on the disenfranchisement of indigenous peoples (Mollett 2021; Aikau and Gonzalez 2019). This has been the case in the Kazakh region of Xinjiang as well. When landless Kazakhs appealed to the authorities, they were immediately construed as a threat to social stability and punished as rioters. In recent years, the crackdown on Turkic

\footnotetext{
I In just one month alone in July 20 I7, the Sayram Lake tourist site had a net income of RMB 0 million ( US\$1.5 million) from ticket sales. According to the 2020 edition of the Bingtuan statistical yearbook (XUAR Bureau of Statistics 2020), in 2019, tourist numbers reached more than 33 million people, and tourism in Xinjiang generated RMB20.7 billion in income - more than half of the revenue ( 56.3 per cent) generated by the service industry. Since 2016 , in Xinjiang's Ili and Altay regions, the number of 'Herder Family Happiness' tourist services has increased by 40 per cent, compared with the Twelfth Five-Year Plan period of 201 I-I5. In 2019 alone, rural tourism in Xinjiang served 10.34 million tourists, resulting in RMB400 million in tourist spending. See Ren (2020).
} 
Muslim minorities has created another instance of 'lucrative chaos' for the state to collaborate with corporate entities to appropriate grassland and imprison Kazakh activists, herders, and peasants (Cliff 2016).

By invoking history and geographical narratives to paint northwestern China as a frontier to be tamed, tourism development in Xinjiang is comparable with what indigenous scholar Teresia Teaiwa (2016) calls 'militourism', in which the US military plays a key but clandestine role in establishing the tourism industry in places ravaged by US imperialism. Whereas the US military concealed its activities, the Xinjiang Production and Construction Corps (新疆生产建设兵团)一or Bingtuan, a paramilitary settler-colonial organisation in Xinjiang-is upfront about its development of Xinjiang's tourism sector. From 2016 to 2020, it made a profit of RMB60 billion from tourism, which is double that made under the previous Five-Year Plan. Bingtuan's tourism services include ecotourism (生态旅游), cultural experiential tourism (文化体验), 'Red' tourism (红色旅游), do-it-yourself road-trips, and wellness vacations, and are mostly offered at tourist sites along the Tianshan range and the Bingtuan towns along the China-Kazakhstan border (Bingtuan Daily 2020). In a China National Tourism Administration bulletin, the state stresses the necessity of tourism for the realisation of the Belt and Road Initiative, as well as the political task of making Xinjiang 'safe' for Han tourists (CNTA 2015). ${ }^{2}$ Tourism companies in eastern China are instructed to pair with tourism companies in Xinjiang to assist in setting developmental priorities in a program called Tourism as Xinjiang Aid (旅游援疆). Following a disaster reconstruction development model, Xinjiang Aid (援疆计划) is a state program that requires Chinese provinces and municipalities to aid Xinjiang through human resources, technology, and investment in Xinjiang's industries. As another top-down state project, this program continues to treat Xinjiang as the involuntary recipient of state development and is leading to a greater influx of Han and more resource extraction in the province. A key priority of Tourism as Xinjiang Aid is to further develop the region's transport infrastructure to provide more convenient travel networks, such as express trains that allow tourists to travel directly from sister cities designated by Xinjiang Aid. The Xinjiang

2 Incarcerated and exiled Uyghurs and Kazakhs see Han people's ability to enjoy tourism in Xinjiang as a social privilege; only they have such free access and mobility. 
Aid program is also heavily involved in a labour transfer program that moves Uyghurs out of Xinjiang and assigns them to factories in the eastern provinces as unfree workers (Xu et al. 2020). Under the state's directive, the tourism narratives propagated by the Bingtuan must champion "land reclamation culture' (屯莀文化): Chinese settler histories claiming that today's Xinjiang is the fruit of Han settlers' selfless, backbreaking efforts to develop the land while defending its borders from hostile foreign forces. Reminiscent of American settler histories of frontier expansion, this myth-building process is an important process of normalisation and disavowal of the settler-colonial processes of removal and dispossession.

In many global contexts, indigenous peoples' land and bodies become the key sites of settler-colonial violence. Across northern Xinjiang, coercive conservation legitimated by ecological civilisation discourses has not only led to the enclosure of pastures and the dispossession of Kazakh pastoralists, but also-in the cases I present in the following sectionsoften become the premise for incarcerating resistors under the guise of maintaining social stability.

\section{Displaced by tourism}

Qarajon is one of the most beautiful and lush prairies in the Tianshan region, which is under the administration of Tekes County in Ili Kazakh Autonomous Prefecture. The Ili prefectural government reported in 2016 that it had banned grazing on 2.4 million $m u$ (1,600 square kilometres) of grassland to restore its ecology (XJYL 2016). While the official report notes that some counties have not fully reimbursed the affected herders and urges local county administrators to refrain from embezzling reimbursement funds, it glosses over the herders' on-the-ground struggles against the authorities. In 2011, the prefectural government implemented the grazing ban without consent from the villagers, and Tekes County officials embezzled the reimbursement money that was supposed to be paid to them. According to a whistle-blower, the banned area in Qarajon (500,000 mu, or 333 square kilometres) provided a livelihood for 
204 households engaged in animal husbandry. ${ }^{3}$ Not only did the herders not receive any state reimbursement (set by the authorities at RMB50/ $m u$ or 670 square metres), but also the police hastily drove them off their land. Consequently, many livestock starved, were preyed on by wolves, or, when chased by police cars, fell to their death over a cliff. When herders petitioned in May 2012 to be compensated for the enormous economic loss they had suffered, of both land and livestock, they received only $\mathrm{RMB} 13 / m u$ for $450,000 \mathrm{mu}$ (300 square kilometres) of land-less than one-quarter of the amount they had been promised.

Tekes County's Party Secretary Liu Li claimed that the key to achieving UNESCO World Heritage designation was to ban grazing, and the county had plans to relocate the herders and break their tradition of nomadic pastoralism in favour of rearing livestock in pens (Yuan and Xu 2012). When the prefectural government implemented the grazing ban, it gave Qarajon herders only three days to move, after which they would be driven off the land by force. In a leaked video of the Qarajon incident, Kazakh women were filmed trekking off their land on foot, clinging on to their children and their belongings. They were indignant that the government had sent trucks to demolish their homes, saying their land had already been allocated to tourism sites, and many of their calves had died after being chased by police vans. They complained that state cadres had pressured them to sign the relocation papers, which they refused to do because their husbands were not around. Still, they were evicted, and did not know where to go.

3 The Qarajon riots of 2014 (Қаражон оқиғасы; 2014 喀拉峻事件; كسى were documented by an anonymous whistle-blower, whose video on Youku, a Mainland Chinese video streaming site, was subsequently censored and removed. The video is now available on YouTube (202 Ia). This anonymously edited video contains a state media report from China Central Television (CCTV), screenshots of government documents, a rare clip of herders who have just been evicted from their homes, as well as scenes of protest and subsequent mass arrests in Qarajon. Subtitles that criticise the local government are juxtaposed with the official state narrative. They criticise Tekes County officials' embezzlement of the state funds that are meant to reimburse the dispossessed herders. The video exposes the lies of Tekes County officials. For example, on 3 December 201 I, the head of the Grassland Management Office, Meng Gujiang, said on CCTV that he had banned pastoralism on 70,000 mu (47 square kilometres) of land. He also claimed the government had publicly informed the affected herders of the reimbursements made available to them. However, the real prohibited area was much larger, and the herders were not informed of the reimbursements. The video also notes that state media reports about positive changes in Qaradala village in Tekes County were fabricated. Herder Bahtiyar was instructed to say that his life conditions had improved after sedentarisation measures were implemented, that he had received the RMB50/mu reimbursement, and that his livestock numbers had increased. The livestock were actually borrowed from his neighbours for the purpose of shooting the video. 
Later in the YouTube video, Kazakh men protesting their evictions tried to reason with the state police and cadres, citing the country's grassland laws to argue for their legal right to access the grassland they had lived on for generations. One of them reproached the cadres:

\begin{abstract}
Since this country was founded, it has been amiable and kind to us, but regarding the Qarajon issue, the government has committed a crime whose graveness is unheard of! We believe the government's methods in handling us are wrong ... the learned intellectuals of law and politics like you in those 50 vehicles that came yesterday had no right to drive people and their livestock off the land! What a crime they have committed! [The work-team leaders] also tried to intimidate our entire Kabsalang Village, scaring our children and wives by saying 'your father misspoke' and 'your father has made a mistake.
\end{abstract}

In Xinjiang, work-team leaders, who belong to the lowest level of government, propagandise state policies and hold immense power over the indigenous citizens they 'supervise'. Based throughout the rural areas of the region, they can decide whether a citizen is 'untrustworthy' (不放 心人员 ) and should be sent to the camps for reeducation. This incident happened before the camp system was fully implemented; still, the leaders could have had the herders arrested as a threat to social stability. The Kazakh protester in the YouTube video continued:

It's been four days that we have been intimidated like this! We have done nothing but arrive at our seasonal pastures quietly. We just want to let our livestock graze and support our families. What crime have we committed? Why do you oppress us? Why are we so oppressed? Why don't the state intellectuals who have learned the laws carefully think this through? Can the government right this wrong or not? If not, we will sue and take legal measures. We will ask for compensation for the psychological damage you inflicted on our people. Alas! Some people's cows died, and our children were frightened ... Do you know how many days people haven't had a proper meal here? I haven't even had a cup of water! I've been here day and night! [Asking everyone at the protest:] Do you see anyone set up their tent? Has anyone here sat down to eat? 
To quell the protest, the judicial police-led by Ili sub-branch Party Secretary Zhang Zhide, Tekes County Attorney-General Mutallip, and Inspector Serikjan - were accompanied by more than 100 police cars sent by Police Bureau Chief Wang Xinwei to arrest the resisting herders. For three days, the mountains and valleys echoed with the sound of police sirens and the panicked wails of livestock being chased down by police cars. Ili Kazakh Prefecture Animal Husbandry Bureau Party Secretary Hou Jianxin said: 'It just takes arresting five or six herders to shut them all up' (逮捕五六个牧民都全都老实了) (YouTube 2021a).

After the herders' forced relocation, their land was up for grabs. Through an under-the-table deal, the Ili and Tekes officials transferred the rights for 1.28 million $m u$ (853 square kilometres) of grassland to Haoxinzhong Tianshan (浩新中天山旅游股份有限公司), a joint venture between the local government and a private tourism development company. The company was renamed Kalajun Investment Company (喀拉峻投资股份有限公 司) in March 2012 to manage Qarajon as an 'international ecotourism site' (喀拉峻国际生态旅游区) (Tuniu.com 2006-21). ${ }^{4}$ The company then commissioned the XUAR Environment Protection Technology Centre (新疆维吾尔自治区环境保护技术咨询中心) 一an institution under the administration of the XUAR Environment Protection Bureau-to assess the Qarajon ecotourism construction project without consulting the herders most affected it. In 2013, Qarajon received designation as a UNESCO World Heritage site and, in 2016, it attained the national 5A title to cement its status as a top ecotourism site in China. It was reported that the company had plans to invest RMB1 billion to develop tourism in the area (Liu 2014). ${ }^{5}$

\section{Disappearance of land petitioners}

In July 2013, two years after the Qarajon incident, a Kazakh man named Nurbaqyt Nasihat, who was a student in the Economics Department of Wuxi's Jiangnan University, Jiangsu Province, started to write appeal

\footnotetext{
4 Xinjiang Kalajun Investment Company Limited (新疆喀拉峻投资股份有限公司) has registered capital of RMBI30 million. Xinjiang Morning Post (2018) reported the story of Chen Gengxin and Wang Guozhi coming to invest in Qarajon. Originally from Guangzhou, Chen attended graduate school in the United States and returned to China to do business. In 20I I, the first time he visited Qarajon with Wang, he was impressed and immediately thought of turning the area into 'China's Yosemite' (中国的黄石公园).

5 The company invested RMBI billion to develop tourism in Qarajon (Liu 20|4).
} 
letters on behalf of the herders who had lost their lands in Mori Kazakh Autonomous County (木垒) in the east of Changji Hui Autonomous Prefecture (Xinjiang Victims Database 2018d). The villagers from Shoqpar Tas Village (大石头乡), Bostan Village, and Uzbek Ranch (克木场) sought Nurbaqyt's assistance because he was proficient in Chinese. As was the case in Qarajon, the Mori County Government dispossessed villagers of their land and embezzled large sums of reimbursement funds in the process. In Shoqpar Tas village, 7,000 herders used to steward almost 11.6 million $m u(7,722$ square kilometres) of land. When large tracts of grassland were privatised in the reform era, the Haptik, Dongshan, Hoshur, Kokadir, Salt Lake, and Laojunmiao pastures were enclosed, and the amount of grazing land available shrank to 4,959 square kilometres. As the land use rights for these pastures were held by the Mori Grassland Supervisory Office, the Finance Bureau, the Animal Husbandry Bureau, and various branches of the county government, higher-level officials coordinated to embezzle the reimbursement funds meant for the herders who had to leave their land to make way for mining and road construction projects. ${ }^{6}$

On 10 April 2014, having gathered the signatures of 14,000 herders, Nurbaqyt went with 11 other Kazakhs to petition central government authorities in Beijing. In May, they were taken back to Mori with black hoods over their heads and their ankles in chains, according to the testimony of Nurbaqyt's Kazakhstan-based sister, Mariya Nasihat. ${ }^{7}$ Nurbaqyt's family in Mori were unaware of his whereabouts until a police friend told them of his arrest on the third day after his return to Mori. The police interrogated Nurbaqyt as to why he had gone to Beijing, beating him in hopes of securing a confession, but he insisted that he had not committed any crime. He was then detained for eight months, until the court finally opened his case and sentenced him to two years and eight months for 'assembling a crowd to disrupt social order' (聚众扰乱社会秩 序罪). On 16 July, Nurbaqyt's application for release on bail pending trial was rejected, as the police claimed he was 'too dangerous to be released' (取保候审后不足以防止发生社会危险性). His appeal letter, signed on 20 July, asked the authorities to investigate the corrupt means by which

6 According to Mariya Nusihat's testimony for Nurbaqyt, Mori County leader Kairat sold the 100-year land usage certificate to coal and salt mining companies. Her appeal letter, which outlines the coordinated embezzlement of reimbursements, can be viewed in Nurbaqyt Nasihat's entry on the Xinjiang Victims Database (20 I8).

7 Her testimony was collected by Serikzhan Bilash, the co-founder of Atajurt Kazakh Human Rights Group. 
Mori's officials had enclosed the pastures and displaced the herders. He was confused about why he had been sentenced for simply exercising his civil right to appeal.

The state's intensified crackdown on Muslims in 2016 made it convenient for local authorities to detain petitioners and protesters in Xinjiang who were otherwise not criminalised by the state's Islamophobic policies. As Pittman Potter (2013: 127) points out, "law and policy on economy and development in Xinjiang reflect tensions between efforts to develop agricultural, petroleum, and mineral resources on the one hand, and security programs aimed at suppressing local dissident and separatist movements on the other'. After 2016, laws and policies in Xinjiang consolidated a highly securitised environment to ensure the stability and profitability of resource extraction. Nurbaqyt was released in October 2016 just as Chen Quanguo began the mass crackdown on ethno-religious minorities in Xinjiang, and he had managed to enjoy only a month of freedom when the police sent him, along with the other 11 Kazakh petitioners, to a detention camp to 'study'. Internal reports from the Ürümqi police department leaked by The Intercept show that petitioners are often treated as 'untrustworthy' and subject to detention (Grauer 2021). All the petitioners were subjected to beatings in captivity, according to Mariya. Two were beaten so badly they became disabled and are now reliant on wheelchairs. While Mariya received a phone call from a foreign journalist about Nurbaqyt's release on 24 December 2018, there has been no information about his whereabouts since. The requests by his family, who are currently living in Kazakhstan, for his return remained unanswered. Nurbaqyt's Kazakhstan permanent residency certificate was processed in 2014, but it is not clear whether he will ever be able to get out of Xinjiang.

\section{Land confiscation under crackdown}

In 2017, the Chinese Government deemed Kazakhstan one of '26 sensitive countries' (26个涉恐国家)-Muslim-majority and other countries perceived to be 'harbouring religious extremism. ${ }^{9}$ Many Chinese Kazakhs

8 According to Mariya Nasihat, the 12 land petitioners are Nurbaqyt, Dalelkhan, Janat, Asai, Sayra (F), Elay, Rasul, Kurpari (F), Muwiq, Jarkingul (F), Rahat, and Qumar. Except for Nurbaqyt, the last names of the II other petitioners are unknown.

9 The 26 countries are: Algeria, Afghanistan, Azerbaijan, Egypt, Pakistan, Kazakhstan, Kyrgyzstan, Kenya, Libya, South Sudan, Nigeria, Saudi Arabia, Somalia, Tajikistan, Turkey, Turkmenistan, Uzbekistan, Syria, Yemen, Iraq, Iran, Malaysia, Indonesia,Thailand, United Arab Emirates, and Russia. 
in Xinjiang who used to freely travel to Kazakhstan can no longer do so because their passports have been confiscated by the local police. Many Kazakh nationals are detained in the camps, and their families in Kazakhstan dare not travel to China to visit them. Chinese authorities view Chinese Kazakhs who have visited Kazakhstan as a threat, believing they may publicise the situation in Xinjiang to the international community and undermine bilateral relations. At the same time, the state's expanded repressive capacity has provided authorities with more leverage to coerce Kazakhs and Uyghurs to forfeit their land and assets under threat of being sent to 'study in the camps'.

According to the testimonies collected by the Xinjiang Victims Database, Chinese Kazakhs who have travelled to Kazakhstan, have family in Kazakhstan, or have Kazakh citizenship or a green card have been intimidated by Xinjiang's local governments into giving up their land. ${ }^{10}$ These cases show that the processes that prevented Nurbaqyt from protesting the theft of his land have been accelerated by the internment camp system. Such large-scale theft is no longer an isolated incident; rather, it appears that any Kazakh citizen deemed untrustworthy will be subject to land seizure and detention in the camp system, which has allowed this process to proliferate at a grassroots level.

For example, in 2017, when former farmer Erbolat Zharylqasyn travelled from Kazakhstan to Xinjiang to visit his relatives in Tacheng, the local police demanded he either return the $33 \mathrm{mu}$ (2.2 hectares) of farmland he had been cultivating since 1997 or pay a lump sum of RMB160,000 (Xinjiang Victims Database 2018a). Since he refused to give up his farmland and could not pay the exorbitant fee, the authorities made him renounce his Kazakh citizenship. He has been stuck in Xinjiang ever since, separated from his wife and children. Esqat Bekinur had his passport confiscated by the authorities in Zhaosu County in Ili and the village administration demanded he waive title over his farmland to win back his passport (Xinjiang Victims Database 2018b). Esqat, his older sister, and his brother-in-law have been detained in the camps since 2018, leaving his younger sister and elderly parents without financial support in Kazakhstan. Nagima Sultanmurat, a herder in Zhaosu County in Ili, was forced to sign a document giving up her $705 \mathrm{mu}$ (47 hectares) of

10 Xinjiang Victims Database (202I): 'In numerous documented cases, the state not only detains but also confiscates (land, property, money). We now have a list of (32) entries where this is mentioned.' 
pasture, which was valid until 2047, to get her passport back (Xinjiang Victims Database 2018c). However, after she signed the document, the local police refused to return her passport; they would only do so once her Kazakh family members travelled to Xinjiang and went through the deregistration process. When Kunim Zeinolda, a Chinese citizen with a Kazakh residence permit, returned to Wenquan County in Bortala Mongol Autonomous Prefecture to resolve her pension problems, she had her documents confiscated by the authorities on arrival (Xinjiang Victims Database 2019). She kept returning to the local administration offices to try to get her passport back, but the authorities threatened to send her to a camp to 'study' if she persisted. Later, they offered to return her passport on the condition she abandon her family's $30 \mathrm{mu}$ (2 hectares) of farmland and give up her retirement pension. She had to give up everything she owned to reunite with her family in Kazakhstan. Many people I have talked to over the past few years faced financial difficulties after fleeing to Kazakhstan from Xinjiang because they were unable to access family assets in China or transfer them to Kazakhstan.

The widespread land grabs and mass detentions associated with the camp system have also been detailed by an anonymous assistant police officer (协警) from Changji Hui Autonomous Prefecture in an interview conducted by activist Erkin Azat (2019). During a '100-day strike-hard' (百日严打) campaign in Xinjiang, he and his Kazakh and Uyghur colleagues were mandated to meet a certain quota of arrests for the camps:

Around August and September in 2016, a Hui village protested the government's seizure of their land for the construction of a police station and hospital, during which Hui houses and farmlands were demolished without the villagers' knowledge. About 150 people gathered to protest. We arrested them and sent them directly to the detention camps-there weren't any trials or legal procedures. They are still inside now, and I was assigned to guard the prisoners in a heavy, full-body bomb suit. To this day, this incident remains confidential. Starting in 2015, the government bought Kazakh grassland at cheap prices. In 2016, a private company bought the 
land for touristic purposes. We attended an opening ceremony for that private company, and we heard it was operating on land stolen from the Kazakhs. (Azat 2019)

\section{Disastrous development}

Even though China aims to be a global leader in tackling climate change, ethnic minorities in Xinjiang and their livelihoods have borne the brunt of top-down policies geared towards intensifying extractive activities and economic development. Li Yifei and Judith Shapiro (2019) note that China's version of an ecologically green future is envisioned as being brought about through authoritarian governance, and this is on full display in Xinjiang, where coercive conservation proceeds hand in hand with tourism development that boosts not only national revenue but also Chinese nationalism.

In response to the international condemnation of human rights violations in Xinjiang, spokespeople for the Chinese Party-State often retort by pointing out how Xinjiang's development has stabilised the region and resulted in a booming tourism sector. Though tourism as a development strategy is endorsed by the United Nations, the World Bank, and many developmental nongovernmental organisations as a vehicle for poverty reduction and social advancement for women and minorities, this support rings hollow, especially in settler-colonial contexts such as Xinjiang and the other cases discussed in this essay. When the development of Xinjiang's construction and ecotourism industries is coupled with the CCP's political priority of maintaining stability, the government inevitably draws on its expanded policing capabilities to dispossess indigenous communities of their land and ensnare them in its carceral infrastructure. When the state introduces a mass internment system for all minority people deemed untrustworthy, the settler-colonial processes that are already in motion are amplified. Removal proliferates as a normalised aspect of settler dispossession of peoples deemed to be detainable primitives. 
This text is taken from Xinjiang Year Zero, edited by Darren Byler, Ivan Franceschini and Nicholas Loubere, published 2022, The Australian National University, Canberra, Australia.

doi.org/10.22459/XYZ.2021.11 